\title{
PASAR MODAL DI INDONESIA DALAM PERSPEKTIF FIKIH MUAMALAH
}

\author{
Muhammad Abdul Ghoni \\ Sekolah Tinggi Agama Islam Negeri (STAIN) Curup \\ J. Dr. AK. Gani No. 01, Curup, Kabupaten Rejang Lebong, Bengkulu 39119 \\ Email: muhammadabdulghoni9595@gmail.com
}

\begin{abstract}
Islamic teaching that is a straight path but not a rigid religion, it is a line-giver to the problems encountered by humans in the course of their lives. Muslims should have a concept that contains a way of life to face the development and progress of the times with various problems. One area that is always warm to talk about is the economy. This problem is getting wider, more varied and more complex. It is not uncommon to find it complicated, especially when confronted with Islamic law. One of them is about the capital market. This journal tries to examine from the perspective of jurisprudence about the jala of the existing capital markets. If we look at the system of stock bidding mechanisms in the capital market, it will be clear that there is a similarity with the capital system contained in the conception of Islamic fiqh, known as mudharabah or qirodh. It is seen from the investors, executors, the nature of capital, capital, and profit sharing of the same shape. Thus, the system of buying and selling of shares in the stock market is clearly visible equation with mudharabah in Islamic jurisprudence.
\end{abstract}

Keywords: Capital market, mudharabah, Islamic fiqh

\begin{abstract}
Abstrak: Ajaran Islam yang merupakan jalan lurus tetapi bukanlah agama yang kaku, ia merupakan pemberi garisgaris terhadap berbagai masalah yang ditemui manusia dalam perjalanan hidupnya. Umat islam seharusnya mempunyai konsep yang mengandung jalan hidup untuk menghadapi perkembangan dan kemajuan zaman dengan berbagai masalah yang ditimbulkan. Salah satu bidang yang selalu hangat untuk dibicarakan adalah mengenai perekonomian. Masalah ini semakin hari semakin luas, beragam dan semakin komplek. Hal ini tidak jarang terlihat rumit, terutama jika dihadapkan dengan hukum Islam. Salah satunya adalah mengenai pasar modal. Jurnal ini mencoba untuk mengkaji dari perspektif fikih muamalah mengenai jalanya pasar modal yang ada saat ini. Jika diperhatikan sistem mekanisme penawaran saham dipasar modal akan jelas kelihatan adanya persamaan dengan sistem permodalan yang terdapat dalam konsepsi fikih Islam, yang dikenal dengan istilah mudharabah atau qiradh. Hal tersebut dilihat dari pemodal, pelaksana, sifat modal, modal, dan pembagian keuntungan yang bentuknya sama. Dengan demikian, maka sistem mekanisme jual beli saham di pasar modal jelas tampak persamaannya dengan akan mudharabah dalam fikih Islam.
\end{abstract}

Kata kunci: Pasar modal, mudharabah, fikih muamalah

\section{Pendahuluan}

Sebagaimana diketahui bahwa manusia dalam hidupnya sangat dinamis, yakni bergerak dan berjalan menuju kemajuan yang tidak mungkin dihambat. Perkembangan perjalanan hidup manusia dari waktu ke waktu banyak menemui hal-hal baru dengan menimbulkan masalah-masalah yang tidak kunjung habis. Dengan dasar ini pula, maka manusia yang mengiginkan hidupnya sempurna tentunya tidaklah dapat diam berpangku tangan dengan hanya memperhatikan keadaan hidup dan penghidupan yang semakin hari semakin bergerak.
Ajaran Islam yang merupakan jalan lurus, bukanlah agama yang baku dan kaku, ia merupakan pemberi garis-garis terhadap berbagai masalah yang ditemui manusia dalam perjalanan hidupnya, karenanya pula manusia senantiasa diperintahkan agar berfikir, berusahaa mencari jalan keluar dari berbagai masalah. Umat islam seharusnya mempunyai konsep yang mengandung jalan hidup untuk menghadapi perkembangan dan kemajuan zaman dengan berbagai masalah yang ditimbulkan.

Salah satu bidang yang selalu hangat untuk dibicarakan dan senantiasa muncul ditengah- 
tengah masayarakat adalah mengenai sirkulasai atau peredaran ekonomi, sesuai dengan kemajuan zaman. Masalah ini semakin hari semakin luas, beragam dan berbagai transaksi yang dilakukan manusia untuk memenuhi kebutuhan seperti masalah perseroan, pengkreditan, perkoperasian, asuransi dan persoalan-persoalan ekonomi lanya. Hal ini tidak jarang menjadi rumit, terutama jika dihadapkan dengan hukum Islam. Salah satunya adalah mengenai pasar modal. Jurnal ini mencoba untuk mengkaji dari perspektif fikih muamalah mengenai jalanya pasar modal yang ada saat ini. Oleh dasar itulah maka penulis mencoba membahas tema pasar modal di indonesia suatu tinjauan hukum islam dalam perspektif fikih muamalah.

\section{Pokok-Pokok Pengertian Pasar Modal}

Menurut Husnan ${ }^{1}$, pasar modal didefinisikan sebagai pasar untuk berbagai instrumen keuangan jangka panjang yang dapat diperjual belikan, baik yang diterbitkan oleh pemerintah maupun perusahaan swasta. Haroen ${ }^{2}$ menjelaskan pasar modal pada prinsipnya sama seperti pasar pada umumnya dimana penjual dan pembeli saling bertransaksi, yang membedakannya hanyalah dari segi objek transaksinya yaitu modal. Adapun pasar modal menurut Darmadji dan Fakhruddin ${ }^{3}$ merupakan pasar untuk berbagai instrumen keuangan jangka panjang yang bisa diperjual belikan, baik dalam bentuk hutang, saham, maupun instrumen lainya.

Lebih jauh lagi Tandelilin ${ }^{4}$ menjelaskan, pasar modal adalah pasar yang berisikan sejumlah instrumen keuangan jangka panjang yang diperjual belikan dalam bentuk hutang maupun modal. Disamping itu pasar modal menjadi sarana bagi pihak yang memiliki kelebihan dana untuk menyalurkan dana tersebut kepada pihak yang membutuhkan dana. Definisi diatas

1 S. Husnan, Dasar-Dasar Teori Portopolio dan Analisis Sekuritas. (Yogyakarta: UPP AMP YKPN, 2005), h. 3.

${ }^{2}$ Nasrun Haroen, Perdagangan Saham di Bursa Efek Menurut Hukum Islam, (Padang: IAIN IB Press, 1999), h. 39.

3 T. Darmadji, dan Fakhruddin, Pasar Modal di Indonesia, (Jakarta: Salemba Empat, 2006), h. 1.

${ }^{4}$ E.Tandelilin, Portopolio dan Investasi, Teori dan Aplikasi, (Yogyakarta: Kanisius, 2001), h. 26 menjelaskan, bahwa dalam pasar modal di satu sisi terdapat pihak yang kekurangan modal dan disisi lainya ada pihak yang kelebihan modal sehingga terjadinya transaksi.

Perusahaan yang terdaftar di pasar modal Indonesia, wajib untuk menyajikan informasi perusahaan secara terbuka kepada masyarakat luas. Dalam arti lain memberikan informasi mengenai kondisi perusahaan tersebut baik dari segi profil, produk, aktivitas, hingga kinerja perusahaan itu sendiri (Hartono) $)^{5}$. Perusahaan yang lebih menguntungkan akan medapatkan kesempatan yang lebih besar dalam memperoleh dana dibandingkan dengan perusahaan yang kurang menguntungkan. Hal ini menjadi menarik karena adanya dua pihak yang terlibat yakni pihak pemodal dan pihak pengelola modal.

Berdasarkan pengertian dari beberapa sumber dan pemaparan diatas diketahui sesunguhnya pada pasar modal terdapat pihak yang memiliki modal yang memberikan modalnya terhadap suatu pihak dalam hal ini pihak pengelolah dengan suatu kesepakatan tertentu. Jika dilihat maka pasar modal ini menyerupai akad mudharabah pada fikih muamalah.

\section{Hukum Islam Tentang Pasar Modal}

Setelah memperhatikan uraian terdahulu, maka terlihatlah dengan jelas bahwa pasar modal atau kegiatan pasar modal terjadi transaksi jual beli modal yang berbentuk atau berupa saham di bursa efek, juga termasuk jual beli valuta asing, jual beli komoditi, sertifikat berharga, saham dan lain-lain. Dalam Islam, jual beli hukumnya adalah halal. Firman Allah:

"Allah menghalalakan jual beli dan mengharamkan riba". (Q.S.Al-Baqarah[2): 275)

Sehubungan dengan transaksi pasar modal ini jika dihadapkan pada hukum islam, maka dalam fikih di bagian muamalah atau pada bagian bukan ibadah ada ditemui kajian-kajian mengenai perkongsian atau yang disebut syirka, dalam hukum perdata dikenal dengan istilah partnership dan terdapat juga tentang pasal-pasal,

5 J. Hartono, Teori Portopolio dan Analisis Investasi. (Yogyakarta: BPFE, 2013), h. 450. 
titipan (wadhiah) serta ditemui juga pembahasan mengenai peyerahan modal kepada pihak lain seperti apa yang terjadi pada pasar modal yang mana di dalam fikih disebut mudharabah.

Jika diperhatikan jual beli saham pada pasar modal termasuk kepada kategori mudharabah, sebab emisi di pasar modal sama dengan sistem mudharabah yang ada pada fikih islam. Pada pasar moda salah satu pihak sebagai pemodal (investor) dalam fikih disebut shahibul mal meyerahkan modalnya kepada pihak lain dalam hal ini pihak yang membutuhkan modal (emiten). Kemudian modal tersebut dikelolah atau diinvestasikan dan hasil atau keuntungan (deviden) dibagi sesuai perjanjian yang telah disepakati sebelumnya. Ciri-ciri khusus transaksi seperti ini dalam fikih islam dapat diuraikan sebagai berikut:

\section{a. Pemberi Modal}

Sebagian pendapat ulama menyatakan bahwa salah satu yang harus diperhatikan adalah mengenai kedudukan pemberi modal, apakah ia ikut campur dalam menentukan kebijaksanaan dalam perniagaan atau tidak. menurut mazhab Malik dan Imam Syafi'i bahwa pemilik modal tidak dibenarkan mengikat si pelaksana dalam menetapkan kebijaksanaan (Thohir Abdul Mukhsin Sulaiman) ${ }^{6}$ yang berarti harus bebas dalam bertindak.

\section{b. Pelaksana dan Resiko yang ditanggung}

Menurut ketentuan fikih, transaksi seperti ini dilaksanakan atas dasar adanya saling kepercayaan dari pemilik modal terhadap si pelaksana yang meliputi kecakapanya, pengalamannya dan pengetahuanya serta kejujurannya dalam mengembangkan dan menjalankan usahanya, jadi dalam masalah ini kedudukan si pelaksana sebagai seorang yang sedang mendapat kepercayaan atau menjadi seorang wakil manakala ia sedang bertindak atas usahanya. Maka apabila transaksi telah berlangsung si pelaksana sudah memegang modal, kalau terjadi kerusakan atau kerugian dengan tidak disengaja berdasarkan keterangan yang dapat diterima maka tidak memikul kewajiban apa-apa kebijaksanaan

${ }^{6}$ Thohir, Alajul Musykilah al-Iqtishadiyah fi al- Islam, (Bandung: Al Ma’arif, 1983), .h. 25.
(Thohir Abdul Mukhsin Sulaiman) ${ }^{7}$, berarti tidak dikenakan gantirugi terhadap kerugian. Karena pada dasarnya kerugian yang diderita oleh pemilik modal sama dengan kerugian yang diderita oleh si pelaksana, dimana dia juga telah kehilangan waktu, tenaga atau jerih payah. Lain halnya apabila disengaja dan terjadi pelanggaran oleh pelaksana, maka dia wajib menanggung resiko apabila terjadi kerugian.

a. Pembagian Keuntungan

Menurut ajaran islam keuntungan yang diperoleh pada dasarnya adalah milik kedua pihak, yakni milik si pemodal dan milik si pelaksana. Untuk pembagian dari hasil keuntungan hendaklah presentasenya ditentukan dengan jalan keseakatan kedua belah pihak seperti seperdua, sepertiga, dll. Tidak dapat dibenarkan baik si pemodal maupun si pelaksana menuntut kelebihan dari ketentuan yang telah disepakati kedua belah pihak. Karena cara demikian oleh para ulamah diharamkan (Ibnu Rusy) ${ }^{8}$. Disamping itu tidak pula dapat dibenarkan apabila si pemodal menetapkan untuk bagianya dengan jumlah persentase dari seluruh jumlah modal tanpa memperhatikan serta mempertimbangkan untung atau kerugian yang dialami. (Thohir Abdul Mukhsin Sulaiman) ${ }^{9}$.

b. Modal dan Penafsiran harus jelas

Untuk mempermudah penetapan beberapa jumlah laba atau keuntungan yang diperoleh selama modal dikembangkan dan sekaligus untuk mempermudah perhitungan akir nilai uang selama dikembangkan, semua kekayaan yang ada dikurangi modal yang pernah dan diserahkan sebelumnya, maka diperlukan kejelasan dari modal yang diserahkan. Untuk mengatasi perselisihan di kemudian hari maka dianjurkan agar jumlah harta yang dijadikan modal tersebut tercatat dan jika diperlukan hendaknya terdapat saksi atau pihak ketiga.

c. Sifat Modal

Asy. Syaiyid Sabiq berpendapat bahwa modal

\footnotetext{
${ }^{7}$ Thohir, Alajul Musykilah..., h. 200.

${ }^{8}$ Ibnu, Rusyd, Bidayatul Mujtahid: alih bahasa jilid IX, (Jakarta: Menara Kudus, 1989), h. 60.

${ }^{9}$ Thohir, Alajul Musykilah..., h. 119.
} 
hendaklah bersifat uang tunai. Jika berbentuk emas atau perak batangan, serta barang perhiasan atau barang dagangan, maka tidak sah (Syaiyid Sabiq) ${ }^{10}$. Karena apabila modal itu dengan barang dagangan maka transaksi ini menjadi samar (Ibnu Rusy) ${ }^{11}$.

Dari keterangan diatas ternayata yang menjadi perhatian para fiqoha dalam masalah sifat modal ini sebenarnya mereka berhati-hati untuk menghindari supaya dalam permodalan tidak terjadi ketidakjelasan, karena modal yang terdiri dari bukan uang untuk kemungkinan nilainya akan terjadi tidak jelas. Karena itu, jika modalnya terdiri dari barang, harus dihargakan lebih dahulu dengan uang secara teliti. Berarti barang tersebut hendaklah dihargakan dengan uang terlebih dahulu oleh si pemilik modal bersama dengan pelaksana yang akan dikembangkan (Thohir Abdul Muhksin Sulaiman) ${ }^{12}$. Kemudian modal dapat digabung dengan modal pelaksana. Untuk pembagian keuntungan mula-mula dikurangi untuk peyertaan modal dan kemudian pembagian pemilik modal dan pengelolah. Misalnya masing-masing mengeluarkan dana Rp. 1.000 .000 dan perjanjian keuntungan dibagi seperdua, kemudian mendapatkan laba Rp. 500.000, maka keuntungan dibagi sebagai berikut yakni Rp. 250.000 untuk penyertaan modal tahap kedua. Sedangkan sisanya Rp. 250.000 dibagi sama besar untuk pemberi modal dan pengelolah yakni sama-sama Rp. 125.000.

Jadi jelasnya, bentuk-bentuk sistem permodalan menurut fikih Islam adalah seorang menyerahkan modalnya kepada pihak lain untuk dikembangkan dan keuntunganya nanti dibagi menurut persentase yang telah disepakati bersama.

Kembali kepada pokok masalah tentang pandangan Islam terhadap sistem atau mekanisme yang berlaku pada pasar modal. Jika diperhatikan sistem mekanisme penawaran saham dipasar modal akan jelas kelihatan adanya persamaan dengan sistem permodalan yang terdapat dalam konsepsi fikih islam, yang dikenal dengan istilah h. 36 .

${ }^{10}$ Sayyid Sabiq, Fiqih Sunnah, (Bandung: Al-Ma’arif, 1989),

${ }^{11}$ Ibnu, Rusyd, Bidayatul Mujtahid, h. 6.

${ }^{12}$ Thohir, Alajul Musykilah..., h. 198. mudharabah atau qirodh. Karena sebagaimana yang telah dijelaskan terdahulu pemodal tidak dibenarkan mengikat sipelaksana dalam menetapkan kebijaksanaan yang berarti si pelaksana berkuasa penuh dalam menetapkan kebijakan pengelolaan modal dengan tidak menanggung resiko jika terjadi kerugian, dimana kerugian ditanggung sepenuhnya oleh si pemodal. Sedangkan keuntungan dibagi sesuai kesepakatan bersama dalam persentase yang sudah disepakati. Dengan demikian maka sistem mekanisme jual beli saham di pasar modal jelas tampak persamaanya dengan akan mudharabah dalam fikih Islam.

\section{Penutup}

Dari uraian di atas, dapat diambil kesimpulan sebagai berikut:

1. Antara mekanisme penawaran saham yang berlaku pada pasar modal ada persamaannya dengan sistem permodalan yang terdapat pada fikih Islam, yang dikenal dengan istilah mudharabah.

2. Jika sistem jual beli saham di pasar modal sama dengan mudhhorobah dengan sendirinya hukum pembelian saham halal bahkan dianjurkan.

\section{Pustaka Acuan}

Darmadji, T, dan Fakhruddin, Pasar Modal di Indonesia, Jakarta: Salemba Empat, 2006.

Haroen, Nasrun, Perdagangan Saham di Bursa Efek Menurut Hukum Islam. Padang: IAIN IB Press, 1999.

Hartono, J., Teori Portopolio dan Analisis Investasi, Yogyakarta: BPFE., 2013.

Husnan, S., Dasar-Dasar Teori Portopolio dan Analisis Sekuritas, Yogyakarta: UPP AMP YKPN, 2005.

Rusyd, Ibnu, Bidayatul Mujtahid: alih bahasa Jakarta. Menara Kudus., 1989, Jilid IX.

Sabiq, Sayyid, Fikih Sunnah, Bandung: AlMa'arif, 1989.

Tandelilin, E., Portopolio dan Investasi, Teori dan Aplikasi. Yogyakarta: Kanisius, 2001

Thohir, Alajul Musykilah al-Iqtishadiyah fi alIslam, Bandung: Al Ma’arif, 1983. 